October 2020

Volume 135 Number 5

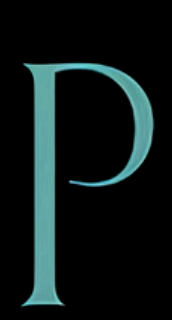




\section{October 2020}

Volume 135 Number 5

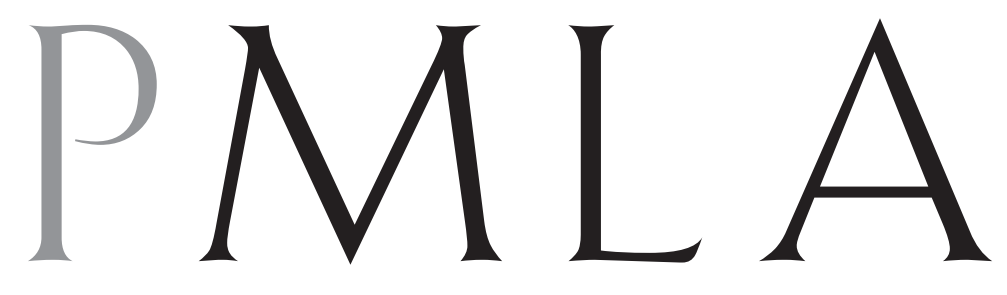

Publications of the Modern Language Association of America 
THE MODERN LANGUAGE ASSOCIATION OF AMERICA

[ Organized 1883, Incorporated 1900

\section{Officers}

FOR THE TERM ENDING 10 JANUARY 2021

President

JUdiTH BUTLER

University of California, Berkeley

First Vice President

BARBARA FUCHS

University of California, Los Angeles

Second Vice President

Christopher John Newfield

University of California, Santa Barbara

Executive Director

Paula M. Krebs

\section{Executive Council}

FOR THE TERM ENDING 10 JANUARY 2021

ERIC HAYOT

Penn State University, University Park Evie SHOCKLEY

Rutgers University, New Brunswick

Dana A. Williams

Howard University

FOR THE TERM ENDING 9 JANUARY 2022

JEAN Elizabeth Howard

Columbia University

Elizabeth Mathews Losh

College of William and Mary

LEAH RICHARDS

LaGuardia Community College,

City University of New York

RAMON SALDIVAR

Stanford University

FOR THE TERM ENDING 8 JANUARY 2023

Ann Kalscheur Suarez

MiraCosta College, $C A$

AnJali PrabHu

Wellesley College

Julie Shoults

Muhlenberg College

FOR THE TERM ENDING 7 JANUARY 2024

LISA KARAKAYA

Graduate Center, City University of New York

JAHAN RAMAZANI

University of Virginia

IgNaCio SÁNCHEZ PRADo

Washington University in St. Louis

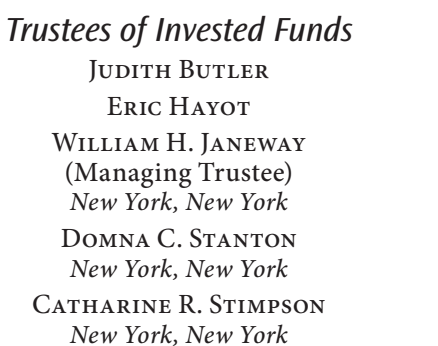

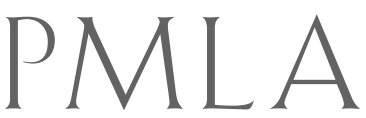

PUBLICATIONS OF

THE MODERN LANGUAGE ASSOCIATION OF AMERICA

[ Published five times a year $]$

Available online at JSTOR and MLAJournals.org; indexed in the MLA International Bibliography.

Editor

WAI CHeE Dimock

Yale University
Director of

Scholarly Communication

Angela Gibson

Head of Periodical Publications

SARA PASTEL

Senior Editor

BARNEY LATIMER
Associate Editors

John D. GolbaCH

JOSEPH WALLACE

Senior Advertising Manager and

Submissions Associate

AnNABel SChNeIder

Editorial Assistant

Isabel Xiaoyue GuaN
PMLA (ISSN 0030-8129) is published five times a year, in January, March, May, September, and October, by the Modern Language Association of America. Membership in the association is open to persons who are professionally interested in the modern languages and literatures. Information about annual dues, which include subscription to $P M L A$, is available at www.mla.org/Membership/About-Membership. Membership applications are available on request and at www.mla.org/Membership/Join-the-MLA.

For libraries and other institutions, a subscription in 2020 to the electronic format of $P M L A$ alone is $\$ 235$ and to the print and electronic formats is $\$ 255$ (domestic and Canadian) or $\$ 290$ (foreign). Subscriptions also include online access to the 2002-19 volumes. Agents deduct four percent as their fee. Claims for undelivered issues will be honored if they are received within six months of the publication date; thereafter the single-issue price will be charged. To order an institutional subscription, call or write MLA Member and Administrative Services (646 576-5166; subscrip@mla.org).

Single copies of issues for the current year and the previous one are available at www .mla.org/store/CID70 and from MLA Member and Administrative Services (646 576-5161; bookorders@mla.org).

The MLA publication and editorial offices are located at 85 Broad Street, Suite 500, New York, NY 10004-2434 (646 576-5000; pmlasubmissions@mla.org).

All communications concerning membership, including change-of-address notifications, should be sent to Member and Administrative Services, MLA, 85 Broad Street, Suite 500, New York, NY 10004-2434 (646 576-5151; membership@mla.org).

Periodicals postage paid at New York, NY, and at additional mailing offices.

(c) 2020 by The Modern Language Association of America. All rights reserved. Printed in the United States of America. MLA and the MODERN LANGUAGE ASSOCIATION are trademarks owned by the Modern Language Association of America.

Library of Congress Catalog Card Number 12-32040. United States Postal Service Number 449-660.

POSTMASTER: Send address changes to PMLA, Member and Administrative Services, MLA, 85 Broad Street, Suite 500, New York, NY 10004-2434. 


\section{Contents}

837 Submitting Manuscripts to PMLA

838 Forthcoming in PMLA

838 Features in PMLA

841 Editor's Column_Languages in the Time of Corona

847 Presidential Address 2020-Literature and the Right to Be Human

859 Reading Distance: Port Louis, Cairo, Beijing Michael Gibbs Hill

877 "You Do It!": Going-to-Bed Books and the Scripts of Children's Literature

ROBIN BERNSTEIN

895 Between Fiction and Physiology: Brain Fever in The Brothers Karamazov and Its English Afterlife

Jacob Emery and Elizabeth F. Geballe

914 Notes on Vegan Camp

EMELIA QuinN

\section{little-known documents}

931 Decadenza

Giorgio Agamben

Introduction AND transLation by DaNiEL LukES

938 A Glossary for the Bible, Chiefly Designed for Children

Eliza Sharples

INTRODUCTION BY SUZANNE L. BARNETT

\section{theories and methodologies \\ Cultures of Argument}

946 Introduction to "Cultures of Argument": The Loose Garments of Argument

Pardis Dabashi
Editorial Board

HeAther Blurton, 2022

University of California, Santa Barbara GALEN BROKAW, 2021

Montana State University, Bozeman

Peter J. Kalliney, 2021 University of Kentucky

MARY MCALPIN, 2022

University of Tennessee, Knoxville

Josephine PARK, 2022

University of Pennsylvania

ILYA VINITSKY, 2021

Princeton University

\section{Advisory Committee}

Eric GARY ANDERSON, 2022

George Mason University

Bernadette Andrea, 2021

University of California, Santa Barbara

Arturo Arias, 2023

University of California, Merced

C. D. Blanton, 2022

University of California, Berkeley

ToBIAs Boes, 2022

University of Notre Dame

KARL AshoKa BRITto, 2021

University of California, Berkeley Jim BROWN, 2023

Rutgers University, Camden

Katharine CAPshaw, 2022 University of Connecticut, Storrs

Natalia Cecire, 2023 University of Sussex

Michael C. Cohen, 2022 University of California, Los Angeles

JefFrey N. COX, 2021

University of Colorado, Boulder

JENNY DAVIDSON, 2022

Columbia University

Cesar Dominguez, 2023

Universidade de Santiago de Compostela

NAtalie EdWARDS, 2023

University of Adelaide, Adelaide

Martin G. Eisner, 2022 Duke University

Maud Ellmann, 2021 University of Chicago

JACQUeline AnN FAY, 2021 University of Texas, Arlington

ERIN D. GRAFF ZIVIN, 2021

University of Southern California

PAOLA S. HernandeZ, 2021

University of Wisconsin, Madison

CAtherine Elizabeth Ingrassia, 2021

Virginia Commonwealth University

BonNie LenORE KyBURZ, 2023

Northern Illinois University

(continued) 


\section{Advisory Committee (continued)}

KathryN LACHMAN, 2021 University of Massachusetts, Amherst Jesse MaCliesh LANDER, 2021 University of Notre Dame

Leila Maria Lehnen, 2022 Brown University

Lital LEVY, 2021 Princeton University

Peter Mallios, 2023 University of Maryland, College Park

Jane Ogden Newman, 2022 University of California, Irvine

MARIO ORTIZ-RoBles, 2021 University of Wisconsin, Madison

JuAN G. RAmOs, 2021

College of the Holy Cross

Alan RaUCH, 2022

University of North Carolina, Charlotte

Charlotte Rogers, 2023

University of Virginia

CARlos RoJAs, 2021 Duke University

Matthew Rowlinson, 2023 Western University

IgNACIO SANCHEZ PRADO, 2022

Washington University in St. Louis

Francesca Canadé Sautman, 2023 Hunter College, City University of New York

Subramanian Shankar, 2023

University of Hawai' $i$, Mānoa

DANiEl SHORE, 2023

Georgetown University

Victor Sierra Matute, 2022 New York University

Jonathan STONE, 2022

Franklin and Marshall College

Nathan Suhr-Sytsma, 2023 Emory University

ELISA TAMARKIN, 2022 University of California, Berkeley

Miriam Thaggert, 2021 University of Iowa

Robert TraIN, 2023 Sonoma State University

Alexandra K. Wettlaufer, 2021 University of Texas, Austin
OCTOBER 2020

956 Generous Argument KathleEN FitzPatrick

963 "Never Punch Down”; or, How We Disagree (Online) Now Erin A. Spampinato

970 An Audacious Argument for Modesty Michael Bérubé

976 Generation and Class Antagonism Grace Lavery

982 Adding versus Arguing: Narratology and Taxonomy Yoon SUn LeE

989 Experts and Encounters ROBERT CHODAT

995 Scenes of Argument Nijah Cunningham

1002 Situating the Method Debates

AMANDA ANDERSON

1009 Waiting for Someone to Argue With Kyle C. Kaplan

1016 Response

Heather Love

1021 In Memoriam

1024 Index of Advertisers

1039 Abstracts 